\title{
DIE ONDERRIG VAN DIE INHEEMSE REG: BEVOEG OF BEPERK DEUR BOEKE?
}

\author{
Elmarie Knoetze \\ BJuris LLB LLM LLD \\ Professor in Privaatreg \\ Nelson Mandela-Metropolitaanse Universiteit \\ Port Elizabeth
}

SUMMARY

The article deals with the teaching of customary law at tertiary level, with specific reference to the lecturer's capability to teach the subject, if not a member of a traditional community. This question inevitably relates to the difference between "official" and "living" customary law. The author comes to the conclusion that whether or not the lecturer can teach customary law, is a matter of course content and the sources from which the content is drawn. Ideally, the content and sources should not be restricted to the "official" version of the discipline, as recorded in textbooks on customary law. A different manner of teaching recognizes that customary law is a dynamic living system, the content of which might be difficult to ascertain. The article concludes with examples of two examination papers on second and final year levels of different universities, illustrating the incorporation of the "living" law in particularly the final year paper.

\section{INLEIDING}

Die artikel het nie ten doel om die pedagogiek en metodiek van die onderrig van die inheemse reg, of enige ander regsdissipline, te bespreek nie. Die onderwerp spruit uit 'n vraag aan die skrywer van 'n senior swart manlike kandidaatprokureur in die Skool vir Regspraktyk met die aanvang van die jaarlikse lesingsessie oor "Customary Practice". Sy vraag was: "In which traditional community did you grow up to equip you to teach us customary law?" Die skrywer het nie in 'n tradisionele gemeenskap grootgeword nie. Sy doseer inheemse reg sedert 1991 op tweedejaarsvlak aan die Nelson Mandela-Metropolitaanse Universiteit (die eertydse Universiteit van Port Elizabeth) en het haar LLD in 2004 aan die Universiteit van Wes-Kaapland in die inheemse reg verwerf. Daarbenewens het sy deeltyds aan die voormalige Vista-Universiteit aandklasse in die vak, en "Customary Practice" of "Aspects of Customary Law" vir etlike jare vir die Skool vir Regspraktyk, aangebied. Dit was in klasverband die eerste keer dat sy met die vraag gekonfronteer is.

\footnotetext{
Na gelang van die aanpassing van die sillabus.
} 
Die onderrig van die inheemse reg as vak gee potensieel tot verskeie vrae aanleiding, waaronder die kandidaatprokureur se bekommernis oor die dosent se geskiktheid om die vak aan te bied, omrede sy nie van tradisionele gemeenskap-herkoms is nie. Op 'n meer objektiewe vlak wissel die vrae van teoreties-filosofies, tot akademies-prakties met verwysing na die LLB-kurrikulum, byvoorbeeld:

(a) Die belang van die vak in die LLB-kurrikulum;

(b) die aanbiedingsvlak van die vak, byvoorbeeld op eerstejaars-, tweedejaars- of finalejaarsvlak;

(c) die inkorporering van die vak in ander regsdissiplines, byvoorbeeld in die erf- en sakereg, delikte- en kontraktereg, of nie;

(d) die boekgebonde-teoretiese, of prakties-empiriese aard van die vak;

(e) gepaardgaande daarmee, die inhoud daarvan; ${ }^{2}$

(f) die vraag of die inheemse reg regsreëls, of die reëls van ander gedraginge, ${ }^{3}$ byvoorbeeld antropologie of religie, bevat, of dit 'n kultuurskepping, blote sosiale normatiewe waardes of 'n kombinasie van enige van bogenoemde daarstel;

(g) die filosofiese onderbou van die vak; en

(h) die verhouding tussen die inheemse reg en die Grondwet van die Republiek van Suid-Afrika, 1996, met verwysing na die erkenning van die inheemse reg as stelsel, en meer spesifiek, die grondwetlikheid van sekere inheemsregtelike gewoontes.

Die vraag na die grondwetlikheid van die inheemse reg en sy instellings is akademies reeds weldeurdag beredeneer en beskryf, ${ }^{4}$ maar omdat die vraag na die aard en inhoud van die vak desnoods na die Grondwet verwys en die Grondwet die Grundnorm van die Suid-Afrikaanse reg is, word dit vir die doeleindes van hierdie artikel oorsigtelik onder die loep geneem alvorens die onderrig van die inheemse reg na gelang van die aard van die vak bespreek word. Aan die kandidaatprokureur: Die skrywers insiens is geen dosent geskik om die inheemse reg te doseer sonder om dit binne die konteks van die Grondwet te doen nie.

\section{INHEEMSE REG IN 'N GRONDWETLIKE BEDELING}

Omdat die inheemse reg oorwegend patriargaal van aard is, is daar reeds

2 Akademies-voorgeskrewe handboeke bevat selde, indien ooit, 'n omvattende beskrywing van die inheemsregtelike publiekereg, waaronder die strafreg. Dit kan onder meer toegeskryf word aan die gebrekkige onderskeid tussen die straf- en deliktereg. Die reg met betrekking tot tradisionele leierskap as deel van die publiekereg word egter wel geredelik bespreek.

3 Olivier, Olivier en Olivier Die Privaatreg van die Suid-Afrikaanse Bantoetaalsprekendes 3uitg (1989) 2.

4 Sien Church "Customary law and the Bill of Rights" in Joubert (red) The Law of South Africa (LAWSA) 2uitg Vol 32 (2009) par 7-12 vir 'n resente algemene oorsig van die inheemse reg en die Handves van Menseregte en volledige verwysings na toepaslike regspraak. Sien ook Bennett Human Rights and African Customary Law (1995) en Customary Law in South Africa (2004) 76-100.

5 Vraag (d) hierbo. 
by die inwerkingtreding van die Grondwet geredelik aanvaar dat sommige inheemsregtelike gewoontes, soos die manlike eersgeboorteregsreël en die manlike opvolging in tradisionele leierskapsposisies, grondwetlik getoets sou word, as synde in stryd met die grondwetlike verbod op geslagsdiskriminasie. ${ }^{6}$ Die debat om die voortbestaan van die inheemse reg word in dié verband gewoonlik as 'n stryd tussen die reg op gelykheid en die reg op 'n kulturele lewe van eie keuse ${ }^{7}$ gekonkretiseer, en daar word aangeneem dat die reg op gelykheid, weens dié reg se sentraliteit in die Handves van Menseregte, noodwendig swaarder weeg as die reg op 'n kulturele lewe. Daar word aan die hand gedoen dat hierdie uitgangspunt nie sonder meer korrek is nie. $^{8}$

Die Handves van Menseregte is 'n morele kode wat namens persone van alle kulture opgestel is. Die inklusiwiteit van die tradisionele Akrika-kultuur blyk uit die geskiedenis van die onderhandelingsproses wat die 1993Grondwet voorafgegaan het. Ingevolge hierdie benadering tot die Grondwet, is dit nie verkeerd om regsreëls, hetsy gemeenregtelik, inheemsregtelik, of statutêr, wat daarmee onversoenbaar is, te wysig nie, mits die tersaaklike grondwetlike bepalings in elke geval vanuit die korrekte kulturele perspektief uitgelê word..$^{9}$ Dit veronderstel dat die debat nie beoordeel moet word op grond van ' $n$ botsing tussen gelykheid en kultuur nie, maar eerder as ' $n$ kwessie van wat Bronstein noem "intra-cultural conflict". Dit wil sê, as 'n swart vrou haar op grond van beweerde geslagsdiskriminasie vis-à-vis manlike tradisionele leiers op regshulp beroep, is die konflik nie noodwendig een van gelykheid versus kultuur nie, maar "rather it is between two different interest groups battling to retain/change power relations within their very culture - a culture which is constantly evolving". ${ }^{10}$ Hierdie benadering blyk om die volgende redes meer aantreklik te wees:

- In die eerste plek verhef dit nie sekere regte van die Handves van Menseregte bo ander regte nie. ${ }^{11}$ In dié opsig is dit ' $n$ meer

6 Ingevolge a 9 van die Grondwet van die Republiek van Suid-Afrika, 1996. Albei gewoontes is mettertyd ongrondwetlik bevind. Vir die ongeldigheid van die manlike eersgeboorteregsreël, sien Bhe v Magistrate, Khayelitsha (Commissioner for Gender Equality as Amicus Curiae); Shibi v Sithole; SA Human Rights Commission v President of the Republic of South Africa 20051 SA 580 (CC), en vir die ongrondwetlikheid van slegs manlike opvolging in tradisionele leierskapsposisies, Shilubana $v$ Nwamitwa 20092 SA 66 (CC). Sien ook Gumede v President of the Republic of South Africa 20093 SA 152 (CC) waar die hof onder meer a 7(1) en (2) van die Wet op Erkenning van Gebruiklike Huwelike 120 van 1998 ongeldig verklaar het omdat dit die huweliksgoederebedeling van inheemsregtelike huwelike gesluit voor die inwerkingtreding van die Wet ingevolge die gewoontereg gereguleer het en vroue, die hofs insiens, daardeur onbillik benadeel is.

Ingevolge a 30 van die Grondwet van die Republiek van Suid-Afrika, 1996.

8 Sien Pieterse "Killing it Softly: Customary Law in the New Constitutional Order" 2000 De Jure 35.

9 Pieterse 2000 De Jure 35, 53.

10 Bronstein "Reconceptualizing the Customary Law Debate in South Africa" 1998 SAJHR 388 403.

11 Nhlapo "African Family Law under an Undecided Constitution: The Challenge for Law Reform in South Africa" in Eekelaar en Nhlapo (reds) The Changing Family: International Perspectives on the Family and Family Law (1998) 628: "This seems to me to provide an important way of sidestepping the potentially pointless pursuit of an absolute ranking of rights which, it is believed, will produce clear answers in all cases of conflict. The balancing 
gebalanseerde benadering as dié wat die voorkeur van die een of ander reg bo 'n ander veronderstel.

- Dit gee potensieel effek aan kulturele regte, sonder om dit direk teen die reg op geslagsgelykheid op te weeg.

- Dit veronderstel 'n gelyke erkenning van verskillende groepe en kulture in ooreenstemming met die grondwetlike waarde van demokrasie. In dié opsig is die benadering getrou aan die waardes van die Grondwet, en is aanduidend van die multi-kulturele aard van die Suid-Afrikaanse samelewing.

- Alhoewel die Handves van Menseregte daarop gerig is om 'n nuwe waardestelsel te skep, veronderstel bogenoemde benadering 'n kompromie tussen Westerse en tradisionele Afrika-waardes. In dié opsig maak dit voorsiening vir die erkenning van 'n pluralistiese regstruktuur vir 'n pluralistiese samelewing.

- Gelyke erkenning van verskillende kultuurgroepe veronderstel nie absolute gelykheid nie. Koyana, met verwysing na die mening van Van der Vyver, ${ }^{12}$ wys in dié verband daarop dat "where a foundation for distinct differentiation is found to be present, justice will in fact not be satisfied by absolute uniformity in the arithmetical sense". ${ }^{13}$

- Die benadering maak voorsiening vir die beoordeling van die reg op 'n kulturele lewe binne die sosio-historiese konteks van die reg, en gee erkenning aan die besondere aard van die tersaaklike inheemsregtelike gewoonte. Die grondwetlike beklemtoning van menswaardigheid ${ }^{14}$ as fundamentele waarde in die Grondwet bemagtig howe om kulturele praktyke en die inheemse reg in konteks te beoordeel. ${ }^{15}$

- Dit maak voorsiening vir die dinamika van die inheemse reg en skep die geleentheid vir die inheemse reg om intern te ontwikkel. ${ }^{16}$

- Dit beskerm die inheemse reg van noodgedwonge verwestersing en homogenisering in die naam van geslagsgelykheid. In dié verband, sê Pieterse:

"Solank as wat inheemse reg nog 'n sosio-kulturele rol het om te vervul, sal dit bly voortbestaan. Om reëls en gebruike wat steeds belangrike samelewingsfunksies vervul sonder verdere oorweging in die naam van menseregte ongeldig te verklaar, sal dit nie in onbruik laat verval nie, maar

approach is particularly important in the South African debate where the view is widely held, for instance, that the right to equality trumps the right to culture."

12 Van der Vyver "Human Rights Aspects of the Dual System Applying to Blacks in South Africa" 1982 CILSA 306.

13 Koyana "Customary Law and the Role of the Customary Courts Today" 1997 Consultus 126 128.

14 Sien, bv, die bepaling in a 36(1) van die Grondwet van die Republiek van Suid-Afrika, 1996, dat die regte in die Handves van Regte beperk kan word in die mate waarin die beperking redelik en regverdigbaar is in ' $n$ oop en demokratiese samelewing gebaseer op menswaardigheid, gelykheid en vryheid.

15 Nhlapo 630.

16 Die hof het in Shilubana supra inderdaad bevind dat die betrokke tradisionele gemeenskap hul inheemse reg intern sodanig in ooreenstemming met die grondwetlike waardes ontwikke het dat vroue ook tradisionele leierskapsposisies kan beklee. 
eerder die gaping tussen 'amptelike' inheemse reg en die wyse waarop inheemse gebruike in die praktyk [dit wil sê, die 'lewende' inheemse reg] kristalliseer, vergroot, wat ten alle koste vermy moet word."1

Bekker beskryf die kenmerk van die sogenaamde "lewende" inheemse reg om sigself intern te vernuwe en die implikasies wat dit vir die grondwetlike erkenning van die inheemse reg het, soos volg:

\begin{abstract}
"Unofficial customary law applied in a chief's court may ... now and again be impugned as being in conflict with human right norms. But the point is that if the official version of customary law should be declared unconstitutional, the unofficial (people's) law will step into the breach and constitute the sole normative order. The constitution-makers will have to decide whether that is what they want. Most of the authors ... point out directly or indirectly that abolishing customary law or declaring aspects of it unconstitutional will not necessarily stop popular practice."
\end{abstract}

Hy kom tot die slotsom dat regshervorming nie gerig moet wees op die geforseerde manipulasie van die inheemse reg in 'n vooropgestelde menseregte-formaat nie. Eerder, "[its] challenge lies in understanding customary law against its own particular philosophical background which is 'communitarian' and to reconcile that with the tenets of individual human rights". "Dit beteken dat die inheemse reg nie intern stagnant is nie; daarbenewens kan howe dit ook ooreenkomstig die gees, strekking en oogmerke van die Grondwet ontwikkel. ${ }^{20}$ Dié ontwikkeling veronderstel die skrywers insiens egter nie noodwendig die afskaffing van die bepaalde gewoonte nie, eerstens omdat die voortgesette erkenning en toepassing van die inheemse reg binne die sosio-ekonomiese en kulturele konteks van die stelsel se funksies beoordeel moet word, en tweedens omdat afskaffing nouliks as die "ontwikkeling" van die reg ingevolge artikel 39(2) van die Grondwet beskou kan word.

In essensie vra die debat om die grondwetlikheid van die inheemse reg as stelsel, of meer pertinent, van spesifieke gewoontes, of dit noodwendig beteken dat in inheemsregtelike aangeleenthede die reg op kulturele lewe noodwendig ondergeskik tot die reg op gelykheid is, en of dit eerder binne die konteks van die funksionaliteit van die gewoonte of beginsel beoordeel moet word. Dit is 'n vraag waarvan dosente en navorsers in die vak, en regsprekers in die algemeen, hulself moet vergewis. Vrae oor die grondwetlikheid van inheemsregtelike gewoontes verleen aan die vakgebied 'n dimensie wat veel verder strek as blote weergawes van algemene beginsels (wat inderdaad onbekend aan die inheemse reg is) en mededelings van interessante gewoontes en stories soos vergestalt in handboeke, populêre tydskrifte en koerantberigte. ${ }^{21}$ Dit laat die vraag

17 Pieterse 2000 De Jure 35-36.

18 Bekker "How Compatible is African Customary Law with Human Rights? Some Preliminary Observations" 1994 THRHR 445.

19 Bekker 1994 THRHR 447.

20 A 39(2).

21 Dit beteken allermins dat handboeke en selfs populêre tydskrifte en koerantberigte irrelevante kennisbronne van die inheemse reg is. Inligting uit hierdie bronne bevat dikwels voorbeelde van die lewende reg. Daarbenewens dien handboeke as toeganklike vertrekpunt vir die bestudering, onderrig en navorsing van die inheemse reg, en bevat dit gewoonlik 
ontstaan of dit wenslik is om die vak reeds op eerstejaarsvlak in die LLBkurrikulum op te neem. Die antwoord hierop val egter buite die omvang van hierdie artikel.

\section{PROBLEMATIEK}

Elk van die vrae gelys in paragraaf 1 oor die aanbieding van die inheemse reg in 'n tersiêre kurrikulum regverdig 'n aparte bespreking, soos blyk uit die oorsigtelike evaluasie van die inheemse reg binne 'n grondwetlike konteks hierbo. ${ }^{22}$ Vir die doeleindes van hierdie artikel, word daar egter gekonsentreer op die vraag na die onderrig van die inheemse reg aan studente, met spesifieke verwysing na die aard daarvan. Die bespreking van dié vraag kan moontlik ook die voorgenoemde kandidaatprokureur se onsekerheid oor die dosent se geskiktheid om die vak te onderrig, in beginsel beantwoord. Die artikel word afgesluit met addenda van twee eksamenvraestelle van verskillende tersiêre instellings as voorbeelde van die assessering van die vak, op verskillende aanbiedingsvlakke, en wat beskrywend is van die verskillende moontlike benaderings tot die aard, en gepaardgaande daarmee, die inhoud van die vak.

Julie Stewart, navorsingsmedewerker van die Women and Law in Southern Africa Research Trust (WLSA), ${ }^{23}$ skryf in 'n bydrae getiteld "Why I Can't Teach Customary Law"24 hoe moeilik dit vir haar was om die inheemse reg in 'n algemene, positivistiese regsraamwerk te doseer. Sy verduidelik dié problematiek soos volg:

"Historically within law curricula in the Southern African region the bulk of teaching on African customary law has tended to be on the captured and formalised versions that are recorded in the law reports, built upon and interpreted through an Anglo-Saxon or Roman Dutch law procedural and substantive law filter. A different starting point for devising curricula is that customary law is a dynamic living system that has the capacity to enrich and inform the other systems of law with which it interacts within a given legal system. This requires a pedagogic approach that investigates the jurisprudence of custom. It postulates that customary law should be approached as a system of cohesive laws with underlying guiding principles that need to be identified, recognised as a source of jurisprudence and their content sensitively explored. It is to this latter approach that I have come to subscribe. Thus whether or not I can teach customary law has become a matter of the content of what is to be taught and the sources from which that content is drawn [beklemtoning voorsien]. If the content is to be the positivist versions of customary law as captured in the textbooks on customary law and the precedents in the law reports then I am ethically bound to critique it at every turn. I can teach it in a technical sense; arguably that is a relatively easy task as it is pre-digested, ordered and homogenised as a coherent set of hierarchical rules, usually arranged in accordance with pre-existing general

waardevolle verwysings na ander relevante bronne, soos regspraak, veral met verwysing na die beslissings van die Appèlhowe vir die Kommissarishowe, wat minder geredelik toeganklik is.

22 Sien par 2, vraag (h).

${ }^{23}$ WLSA is 'n onafhanklike organisasie wat omvangryke navorsing oor onderhoud, die huweliksgoederebedeling en erfreg in Botswana, Lesotho, Mosambiek, Swaziland, Zambië en Zimbabwe gedoen het.

${ }^{24}$ In Eekelaar en Nhlapo (reds) The Changing Family: International Perspectives on the Family and Family Law 217. 
law subject divisions. Just as I can teach the Zimbabweanised Roman Dutch Law of Succession, so I could teach the 'Roman Dutchised' Zimbabwean Customary Law of Succession, but it is not a version which accords with the customs and practices of the peoples of Zimbabwe. However this all begs the question as to what it is that ought to be taught.

Sy kom dan tot die gevolgtrekking dat, "although I cannot ignore the ossified Customary Law in the books, I am compelled to go beyond those versions and explore the underlying principles in the customs and practices of a people." ${ }^{26}$ Van besondere belang is Stewart se mening dat die inhoud en bronne van die inheemse reg bepalend is van haar geskiktheid om die vak te doseer. As gevolg van die ooreenstemmige voorkoms en praktyke van kolonialisme en regspluralisme in onderskeidelik die Suid-Afrikaanse en Zimbabwiese geskiedenis, is Stewart se waarnemings direk vir die SuidAfrikaanse reg relevant.

Uitsprake van die Kaapse Regter-President, John Hlope, dat die SuidAfrikaanse regstelsel eers werklik sal transformeer as dit "verafrikaniseerd" ("Africanized") word, ${ }^{27}$ impakteer direk op die status van die inheemse reg. In dié verband sê hy soos volg: "I believe that people need law that embodies their own culture and their values. We need to Africanize our law and make it relevant to the masses. There is a huge void in our legal system." Dié leemte word syns insiens toegeskryf aan die samesmelting van Engelse en Hollandse reg, ter uitsluiting van die inheemse reg. ${ }^{28}$ Bennett skryf dié tendens toe aan die gevolg van 'n doelbewuste beleid in die Apartheidsjare om Swartes van die deelname aan die ontwikkeling van die Suid-Afrikaanse regstelsel uit te sluit. Dit het gelei tot die uiteindelike verwaarlosing van die inheemse reg, met die gevolg dat dit nie tred gehou het met die ontwikkelende sosiale toestande nie. ${ }^{29}$

\section{4 “AMPTELIKE" VERSUS "LEWENDE” REG ${ }^{30}$}

Vanuit 'n positivistiese perspektief blyk die inhoud van die inheemse reg redelik duidelik uit die amptelike weergawe van die inheemse reg, dit wil sê, wetgewing, hofuitsprake, insluitend dié van die eertydse Appèlhowe vir Kommissarishowe, gewoonte, asook gesaghebbende handboeke en ander

25 Stewart 217-218. Sien ook Sanders "Can Outsiders Understand Indigenous Law?" 1999 Obiter 194197 waar hy na "insiders" en "outsiders", en "inside experience" en "outside understanding" van die inheemse reg verwys. Bennett Customary Law in South Africa 7 wys daarop dat die lewende reg, soos toegepas deur sy subjekte, ontoeganklik vir buitestaanders is. Buitestaanders is per definisie aan die amptelike weergawe van die reg uitgelewer.

26 Stewart 228.

27 Legalbrief Today 16 Julie 2009.

28 Legalbrief Today 10 Julie 2009.

29 Bennett $A$ Sourcebook of African Customary Law for Southern Africa (1991) v.

30 Sanders "How Customary is African Customary Law?" 1987 CILSA 405 onderskei tussen "official customary law", "academic customary law" en "autonomic customary law". Bennett Customary Law in South Africa 7 maak 'n soortgelyke onderskeid, naamlik die sogenaamde "suspisieuse" amptelike weergawe soos toegepas deur die staatshowe en administratiewe burokrasie, die akademiese weergawe wat weens die vooropgestelde persepsies van die skrywers soms onbetroubaar is, en laastens die lewende reg wat die enigste outentieke weergawe van die reg daarstel. 
regsliteratuur. Bennett wys daarop dat met die aanvang van die skryf van inheemsregtelike boeke in Suid-Afrika die oorgrote meerderheid skrywers van Europese herkoms was en dit noodwendig daartoe gelei het dat die tekste gevorm is na aanleiding van "the professional and cultural preoccupations of a European mindset, which included a predisposition to give a privileged status to the written as opposed to the spoken word. ${ }^{.31}$ Dit, natuurlik, omrede die inheemse reg ongekodifiseerd en ongeskrewe is. ${ }^{32}$

Bennett beskryf die onderskeid tussen die lewende en amptelike inheemse reg, en die implikasies daarvan, soos volg:

"All forms of customary law find the basis of their validity in accepted social practice. Thus a rule that was imposed by an external authority or has no local support should be judged invalid. Today so much customary law is of dubious origin that the term is regularly accompanied by a qualifying adjective. 'Living' customary law can be relied upon, since it refers to the law actually observed by African communities; 'official' customary law, the corpus of rules used by the legal profession, must be treated with circumspection [beklemtoning voorsien], for it may have no genuine social basis. Because a living form of customary law is distilled directly from current social praxis, it is subject to continual and imperceptible change, and probably exists only in an oral tradition. It follows that an authentic customary law will lack the precision and conceptual order made possible by writing."

Die onderskeid tussen die twee vorms van die inheemse reg deur akademici noop 'n evaluasie van die onderskeie weergawes van die inheemse reg soos deur die Suid-Afrikaanse howe toegepas.

Daar word algemeen aanvaar dat daar ' $n$ onderskeid tussen die amptelike en lewende inheemse reg is. Daar skyn ook aanvaar te word dat dit die lewende reg, eerder as die amptelike weergawe daarvan, is wat as inheemse reg deur die Grondwet erken word en deur die howe toegepas behoort te word. ${ }^{34}$ Die problematiek verbonde aan die bewys van die lewende inheemse reg ${ }^{35}$ bemoeilik egter die howe se taak om dié weergawe van die reg konsekwent toe te pas. Du Bois wys egter daarop dat die howe

${ }^{31}$ Bennett Customary Law in South Africa 7. Die tendens van blanke skrywers van inheemsregtelike handboeke doen sigself steeds voor. Vanuit 'n Suid-Afrikaanse perspektief is JH Soga, DS Koyana en RB Mqeke prominente voorbeelde van uitsonderings op die tendens. Benewens artikels in geakkrediteerde tydskrifte, dra swart skrywers egter maksimaal by tot die skryf en/of hersiening van hoofstukke in boeke, die deelname aan navorsingsprojekte van die Suid-Afrikaanse Regshervormingskommissie en ander instellings, die opstel van amptelike verslae, die lewering van kommentaar, die deelname aan die wetgewende proses $r e$ die daarstelling, wysiging en/of herroeping van relevante wetgewing, die verwerwing van dikwels ongepubliseerde verhandelinge en proefskrifte, asook die lewering van referate by algemene regs- en vakkongresse, nasionaal en internasionaal.

32 Bennett Customary Law in South Africa 2.

33 Bennett Human Rights and African Customary Laws 60-61.

34 Sien Du Bois "Sources of law: Customary law and other sources" in Wille, Du Bois en Bradfield (reds) Wille's Principles of South African law 9uitg (2007) 103, met verwysing na Himonga en Bosch "The Application of African Customary Law under the Constitution of South Africa: Problems Solved or Just Beginning?" 2000 SALJ 306. Sien ook Lehnert "The Role of the Courts in the Conflict between African Customary Law and Human Rights" Part 2 2005 SAJHR 241 246-247. Lehnert is van mening dat die grondwetlik-erkende reg op kulturele lewe van eie keuse nouliks na die verwronge amptelike weergawe van die reg kan verwys.

${ }^{35}$ Sien par 52 hieronder. 
die lewende reg kan toepas deur gebruikmaking van artikel 39(2) van die Grondwet wat die hof magtig om die reg na gelang van veranderde waardes en praktyke te ontwikkel. ${ }^{36}$ Die ontwikkeling van die reg moet uiteraard in ooreenstemming met die gees, strekking en oogmerke van die Handves van Menseregte wees. Daar blyk sonder meer aanvaar te word dat die hof in Mabena $v$ Letsoalo ${ }^{37}$ die lewende inheemse reg deur middel van die ontwikkeling van die reg erken het deur 'n moeder toe te laat om vir lobola te onderhandel. ${ }^{38}$ Die skrywers insiens behoort die ontwikkeling van die reg nie met die lewende reg gelykgestel te word nie, omdat die lewende reg nie noodwendig die gees, strekking en oogmerke van die Grondwet vergestalt nie. In Mabena het die hof nouliks na die beginsels van ontwikkeling aan die hand van die lewende reg verwys. Lehnert wys egter daarop dat die hof in dié saak albei sy verpligtinge nagekom het, naamlik om die inheemse reg te ontwikkel en om die lewende reg toe te pas. ${ }^{39}$

In die nou reeds bekende saak van $B h e^{40}$ moes die hof oor die grondwetlikheid van sekere statutêre erfregtelike bepalings ten opsigte van swart boedels, sowel as die inheemsregtelike gewoonte van die manlike eersgeboorteregsreël beslis. Die vraag het onder meer ontstaan of die hof die manlike eersgeboorteregsreël ooreenkomstig die grondwetlike waardes kon ontwikkel eerder as om die reël in stryd met die Handves van Menseregte, en dus ongeldig, te verklaar. Die hof se beredenering in dié verband was soos volg: Die hof sou eerstens die ware inhoud van die relevante inheemse reg, soos dit huidig toegepas word, ${ }^{41}$ moes bepaal. Daarna sou die hof die lewende reg aan die bepalings van die Handves van Menseregte moes toets. ${ }^{42}$ Die hof het in beginsel die konsep van die lewende reg vis-à-vis die amptelike weergawe van die reg erken, maar in casu bevind dat daar te min getuienis en materiaal voor die hof geplaas is om die reg dienooreenkomstig te ontwikkel. Die hof het daarop gewys dat "[t]he difficulty lies not so much in the acceptance of the notion of 'living' customary law, as distinct from official customary law, but in determining its content and testing it, as the Court should, against the provisions of the Bil of Rights." ${ }^{43}$

In die onlangse saak van Shilubana $v$ Nwamitwa ${ }^{44}$ moes die hof oor die geldigheid van die opvolging van ' $n$ vrou in die posisie van tradisionele leier in die Valoyi-tradisionele gemeenskap beslis. Die uitspraak is van besondere belang omrede die Grondwetlike Hof verskeie faktore geïdentifiseer het ten einde te bepaal welke weergawe van die inheemse reg in 'n gegewe feitestel

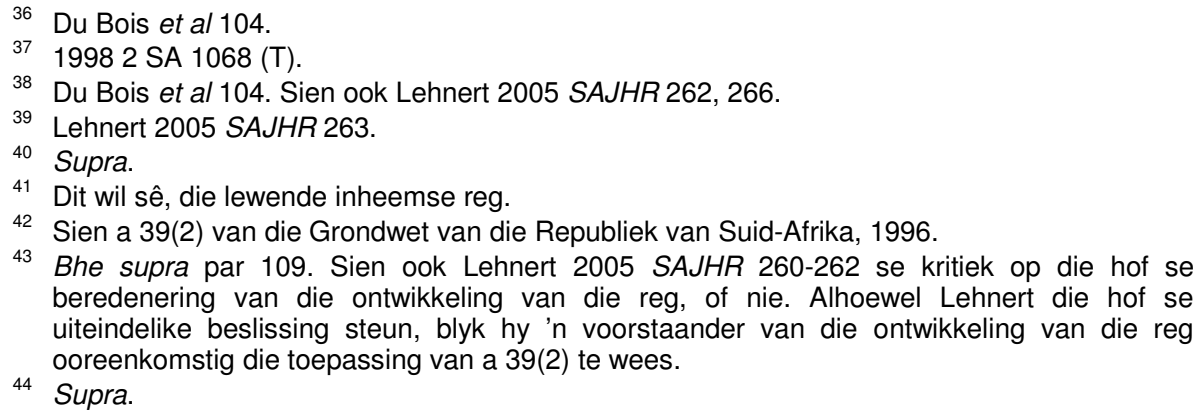

43 Bhe supra par 109. Sien ook Lehnert 2005 SAJHR 260-262 se kritiek op die hof se beredenering van die ontwikkeling van die reg, of nie. Alhoewel Lehnert die hof se uiteindelike beslissing steun, blyk hy 'n voorstaander van die ontwikkeling van die reg ooreenkomstig die toepassing van a 39(2) te wees.

44 Supra. 
van toepassing is. Die hof som die faktore soos volg op:

"[W]here there is a dispute over the legal position under customary law, a court must consider both the traditions and the present practice of the community. If development happens within the community, the court must strive to recognise and give effect to that development, to the extent consistent with adequately upholding the protection of rights. In addition, the imperative of $s 39(2)$ must be acted on when necessary, and deference should be paid to the development by a customary community of its own laws and customs where this is possible, consistent with the continuing effective operation of the law.

Die onderskeie faktore, in fyner besonderhede, is soos volg: ${ }^{46}$

- Die historiese gebruike ("past practice") van die betrokke tradisionele gemeenskap;

- die inheemse reg in tradisionele kleding, verwyder van die gemeenregtelike paradigma;

- 'n versigtige benadering tot die historiese weergawe van die betrokke gewoonte, as gevolg van die tendens van ouer gesag om die inheemse gewoontes te verwring en vervorm;

- gemeenskappe se reg om hul eie gewoontes in 'n vinnig-veranderende wêreld te ontwikkel, in ooreenstemming met die dinamiese aard van die inheemse reg;

- die tans-geldende gewoontes van die tradisionele gemeenskap, met ander woorde, die lewende reg;

- die feit dat die inheemse reg, soos ander regstelsels, mense se lewens reguleer;

- die opweging van die imperatief om ontwikkeling te fasiliteer versus die behoefte aan regsekerheid, respek vir reeds gevestigde regte, en die beskerming van grondwetlike regte;

- die implikasies van verandering vir beide grondwetlike en ander (subjektiewe) regte;

- die proses waardeur verandering plaasvind;

- die impak van verandering op die mees weerlose partye of groepe; en

- die bepalings van artikel 39(2) van die Grondwet.

Van besondere belang is dat die Grondwetlike Hof in Shilubana nie self die reg ingevolge artikel 39(2) ontwikkel het nie, maar gevolg gegee het aan die ontwikkeling wat die hofs insiens, reeds in die tradisionele gemeenskap self plaasgevind het. Dit veronderstel uiteraard die toepassing van die lewende inheemse reg deur die hoogste hof in Suid-Afrika.

45 Supra par 49.

${ }^{46}$ Par 44-48. 


\section{METODIEK VIR DIE VASSTELLING VAN DIE INHEEMSE REG}

Bennett identifiseer die volgende twee algemene metodes vir die vasstelling van die inheemse reg:

"[Since] [c]ustomary law derives from social practices ... [n]ormative systems of this nature are never directly accessible to the outsider. They must be discovered by questioning informants and on-the-spot observation, which are methods typical of the social sciences, or by consulting authoritative texts, which is the traditional legal method. In either case, the resulting data present a construction of reality that is coloured by the preconceptions of the informants and the researchers."

Bennett onderskei tussen wat genoem kan word eie waarneming ("on-thespot observation") en die gebruikmaking van gesaghebbende bronne. Vir die dosent beteken laasgenoemde die gebruikmaking van die amptelike bronne van die reg. "Eie waarneming" verwys onder meer na wat in leketaal bekend staan as "veldnavorsing". Die dosent kan gebruik maak van die resultate van sy eie veldnavorsing, of dié van ander.

'n Vir die dosent nuttige, en student interessante, metode van vakaanbieding, is die vervlegting van die amptelike en die lewende reg wat onder meer deur De Villiers van die Universiteit van Wes-Kaapland gebruik word, en deur hom as die "spicing" van die sillabus met voorbeelde van die inheemse reg genoem word. ${ }^{48}$ Die voorbeelde van die lewende reg wat gebruik word, spruit uit 'n verskeidenheid van bronne, byvoorbeeld jarelange ondervinding by verskeie universiteite, eie waarneming tydens veldnavorsing, vertellings en mededelings deur kollegas en studente, koerant- en nuusberigte, televisieprogramme, tydskrifte en die internet. Let egter daarop dat die hof kragtens artikel 1(1) van die Wysigingswet op Siviele Bewyslewering ${ }^{49}$ nie geregtelik kennis sal neem van die inheemse reg wat nie met voldoende sekerheid vasgestel kan word nie. Dié bepaling word hieronder bespreek. ${ }^{50}$

\section{Eie waarneming/veldnavorsing}

Hoe sou Julie Stewart te werk gaan om haar buite die amptelike weergawe/s van die inheemse reg van die onderliggende beginsels van die gewoontes en praktyke van tradisionele gemeenskappe te vergewis ${ }^{51}$ Beteken dit noodwendig dat die dosent self primêr as waarnemer kennis van die lewende reg moet opdoen deur middel van verblyf in 'n tradisionele gemeenskap (sien die vraag aan die skrywer deur die kandidaatprokureur), deur veldwerk, of deur die gebruikmaking van bronne wat die lewende reg

\footnotetext{
47 Bennett Customary Law in South Africa 1.

48 De Villiers "Spicing the Syllabus with Living Customary Law Examples" ongepubliseerde referaat gelewer by die $7^{\text {th }}$ Annual Law Conference of the Western and Eastern Cape Universities, NMMU, Port Elizabeth, 18 Januarie 2010.

4945 van 1988.

50 Par 52.

51 Stewart 228. Sien par 3 hierbo.
} 
suggereer, byvoorbeeld data deur ander veldwerkers versamel en verwerk?

Met sewe Provinsiale Huise van Tradisionele Leierskap, en dus sewe provinsies met tradisionele gemeenskappe in Suid-Afrika, veronderstel die inwinning van navorsingsinligting 'n grootskaalse navorsingsprojek. In 'n Suid-Afrikaanse konteks bepleit Lehnert navorsing wat die skrywers insiens in omvang met die WLSA-projek vergelyk kan word:

"[T]he lack of research material on the living law should not result in the courts generally refusing to develop customary law. Instead, it underscores that more research material must be made available to the courts so that customary law will be able to be developed. Thus, future research into the living customary law of South Africa should be supported and become a priority."

Let egter op Bennett se waarskuwing dat die inligting en data deur veldwerkers en navorsers ingewin, dikwels deur hul eie vooropstellings onbewustelik as die werklikheid voorgehou word. ${ }^{53}$

Eie waarneming as navorsingsmetode is allermins ' $n$ eenvoudige taak, veral gegewe die dinamiese aard van die inheemse reg wat na gelang van omstandighede sigself van tyd tot tyd intern kan aanpas. Die interne ontwikkeling van die inheemse reg is nie vreemd nie; die buigsame aard daarvan maak interne aanpassings en modifikasie moontlik na gelang van die behoeftes van die gemeenskap en die vervulling of nie-vervulling van die besondere funksies van 'n bepaalde gebruik. ${ }^{54}$ Die vraag is hoe waarneembaar sodanige ontwikkeling is. Coertze verklaar dat die interne ontwikkeling van ' $n$ gewoonte ' $n$ geleidelike proses is:

"It is common knowledge in anthropology that a process of culture change is not characterized by a sudden transition from one way of life to another. There is always a gradual shift, over succeeding generations, from the old to the new order. In the transitional period various stages of synthesis between conflicting culture patterns may be found. This also applies when differing legal systems come into contact with one another. Lawyers faced with the task of finding a solution to a conflict of law problem might discover their answer in studying the ways in which the peoples themselves have resolved the conflict ${ }^{55}$ [beklemtoning voorsien].

Die identifisering van die manifestasie van veranderde gewoontes is in regsformaat potensieel problematies vir die waarnemer, en wel om die volgende redes:

- Daar is reeds gelet op die geleidelike aard van interne ontwikkeling. Vir die waarnemer kan dit tot 'n onbeperkte tydperk van observasie lei. Die WLSA-projek het oorspronklik vir navorsing op 'n regionale of streeksvlak oor 'n twee jaar-siklus voorsiening gemaak, waarna data versamel en geanaliseer is. ${ }^{56}$ Die projek het uiteindelik etlike jare geduur.

52 Lehnert 2005 SAJHR 269-270.

53 Bennett Customary Law in South Africa 1.

54 Nhlapo 624.

55 Coertze "Apparent Conflict in the Indigenous Law of Succession and Inheritance" in Sanders (red) Southern Africa in Need of Law Reform (1981) 42.

56 Sien Chuulu en Chileshe-Musanya "Field Research on Customary Law: Method, Organization and Problems Encountered" in Bennett en Rünger (reds) The Ascertainment of 
- In die tweede plek veronderstel die lewende inheemse reg nie noodwendig 'n eenvormige inheemsregtelike stelsel nie; inteendeel, die voorkoms van ongeveer 800 verskillende tradisionele owerhede en gemeenskappe in Suid-Afrika ${ }^{57}$ is potensieel aanduidend van die wisselende omvang van die navolging van bepaalde gewoontes.

- Daar kan voorsien word dat daar nie noodwendig eenstemmigheid onder tradisionele leiers, sowel as ander belangedraers, ten opsigte van die toepassing van 'n bepaalde praktyk as gewoonte sal wees nie.

- Uiteraard sal regsekerheid in so 'n stelsel ingeboet word.

- Daar word dikwels geredelik aanvaar dat stedelike swartes die inheemsregtelike praktyke en gebruike afgesweer het of verwaarloos, maar Church is van mening dat dit nie sonder meer 'n korrekte veronderstelling is nie, ${ }^{58}$ ' $\mathrm{n}$ tendens waarmee die waarnemer rekening moet hou.

Vir diegene wat nie met die metodiek van veldnavorsing vertroud is nie, kan die navorsing potensieel deur verskeie faktore, hetsy logisties of prakties, bemoeilik of vertraag word, byvoorbeeld:

- die keuse van 'n teikengroep;

- die ontoeganklikheid van teikengroepe in bepaalde geografiese gebiede;

- die gebrek aan mannekrag in afgeleë landelike gebiede;

- taalstruikelblokke;

- die transkripsie van data;

- die verwerking van data;

- die statistiese analise van data en die validasie daarvan; sowel as

- die uiteindelike tydsduur van die navorsing.

'n Multi-dimensionele benadering tot veldnavorsing blyk dikwels bruikbaar en geskik vir regsnavorsing te wees. ${ }^{59}$ Dit veronderstel dat beide primêre en

Customary Law and the Methodological Aspects of Research into Customary Law: Proceedings of Workshop, February/March 1995 (1996) 104.

57 Bekker, Rautenbach en Goolam (reds) Introduction to Legal Pluralism in South Africa 2uitg (2006) 123

58 Church "Constitutional Equality and the Position of Women in a Multi-cultural Society"1995 CILSA 289300.

59 Sien die modelle van Prinsloo "Restatement of Indigenous Law" 1987 CILSA 411; Chuulu en Chileshe-Musanya in Bennett en Rünger (reds) The Ascertainment of Customary Law and the Methodological Aspects of Research into Customary Law: Proceedings of Workshop, February/March 1995 106-112; Becker en Hinz "Customary-law Research in Namibia: Methodological Remarks" in Bennett en Rünger (reds) The Ascertainment of Customary Law and the Methodological Aspects of Research into Customary Law: Proceedings of Workshop, February/March 1995 85-89; Becker "Experience with Field Research into Gender and Customary Law in Namibia" in Bennett en Rünger (reds) The Ascertainment of Customary Law and the Methodological Aspects of Research into Customary Law: Proceedings of Workshop, February/March 1995 93-97; Stewart "Field Research on Customary Law: Gender Awareness A Framework for a Method Adapted to the Social Target Groups" in Bennett en Rünger (reds) The Ascertainment of Customary Law and the Methodological Aspects of Research into Customary Law: Proceedings of Workshop, 
sekondêre bronne vir dataverskaffing benut kan word. Primêre bronne behels onder meer onderhoudvoering met informante, tradisionele leiers, wykshoofde, gemeenskapsleiers, landdroste ${ }^{60}$ en ander persone belas met regspleging. Sekondêre bronne verwys onder andere na toepaslike literatuur, hetsy regstegnies of sosiologies/antropologies van aard, sowel as hofverslae van laer en hoër howe. ${ }^{61}$ Bennett bevraagteken egter die nut van die siviele hofverslae (van die Appèlhowe vir Kommissarishowe) as weergawes van die reg as synde op die presedenteleer gebaseer en daarom ' $n$ voortsetting van ' $n$ reeds verwronge sosiale basis, met as doel die een of ander verborge agenda. ${ }^{62}$ Die skrywers insiens is dié kritiek op die nut van sodanige hofverslae besonder fel. Benewens die fisiese en finansiële toeganklikheid van die kommissarishowe, het dit ook voorsiening gemaak vir swart assessore. Indien die voorsittende amptenaar, die kommissaris (later die landdros), dit wenslik geag het, kon hy die bystand van swart assessore oproep, indien nodig. Die assessore se menings is op skrif gestel en het deel van die hofrekord geword. ${ }^{63}$ Ongelukkig beskik nie alle hof- en universiteitsbiblioteke oor volledige stelle hofverslae van die eertydse Appèlhowe vir Kommissarishowe nie. Dit is egter verblydend dat sommige Regsfakulteite/-skole in die Oos-Kaap steeds sodanige hofsake as deel van hul kurrikula aan studente voorskryf. ${ }^{64}$

Die beslissings van die tradisionele howe van kapteins en hoofmanne, in soverre dit op skrif gestel en toeganklik is, is van besondere nut omdat dit potensieel die mees getroue weergawe van die inheemse reg op daardie tydstip vergestalt. Ingevolge die hofprosedurereëls ${ }^{65}$ moet ' $n$ kaptein (nou ' $n$ senior tradisionele leier) as voorsittende beampte 'n skriftelike verslag in viervoud opstel, met die volgende inligting: die name van die eiser en

February/March 1995 116-118; en Donzwa "Strategies for Research into Customary Law and Women's Rights" in Bennett en Rünger (reds) The Ascertainment of Customary Law and the Methodological Aspects of Research into Customary Law: Proceedings of Workshop, February/March 1995 119-123.

60 Voor 1986 kommissarisse, die voorsittende beamptes van kommissarishowe ingevolge a 17 van die Swart Administrasiewet 38 van 1927. Die kommissarishofstelsel is kragtens die Wet op die Afskaffing van Spesiale Howe vir Swartes 34 van 1986 afgeskaf. Die Wet op Landdroshowe 32 van 1944 is deur die invoeging van a 54A gewysig om voorsiening te maak vir die aanhoor deur landdroste van gedinge tussen swartes, en sedert 1988 deur alle howe, selfs met slegs een swart litigant, kragtens a 1(1) van die Wysigingswet op Siviele Bewyslewering 45 van 1988. Sien Olivier et al 580-609 vir 'n breedvoerige uiteensetting van die hofstelsel.

61 Hofrekords is ongelukkig nie altyd volledig nie, omdat dit nie noodwendig alle relevante gegewens, soos die partye se agtergrond, en die presiese aard van die aangeleentheid of goed in gedrang, bevat nie. Tydens die skrywer se LLD-navorsing oor die swart vrou se reg om te erf, het waarneming in 2003 in die New Brighton-landdroshof, Port Elizabeth, getoon dat geen statistiese gegewens versamel is ten opsigte van die verdeling van swart boedels nie, en dat die aanwysing van 'n verteenwoordiger van 'n intestate swart boedel weens die toe nie-vereiste indiening van 'n likwidasie- en distribusierekening, nie opgevolg is nie, tensy 'n dispuut in die verdeling van die goed ontstaan het. Daar was ook nie 'n behoorlike liasseerstelsel en genoegsame bergingsruimte vir dokumentasie nie. Relevante gegewens is ook nie noodwendig op 'n sentrale plek geberg nie.

62 Bennett Customary Law in South Africa 7.

63 Olivier et al 593.

${ }^{64}$ Soos blyk uit die eksamenvraestelle van Prof RB Mqeke, Rhodes-Universiteit, en die studiemateriaal opgestel deur die nou-afgetrede Prof DS Koyana van die Universiteit van Fort Hare.

${ }^{65}$ Reg 7 van Goewermentskennisgewing R2082 van 29 Desember 1967. 
verweerder, die besonderhede van die eis en die verweer, die uitspraak, en die datum van die uitspraak. Die tradisionele leier en twee lede van die hof moet die dokument onderteken en afskrifte word aan die eiser, verweerder en eertydse kommissaris (later landdros), verskaf. Een kopie word vir rekorddoeleindes deur die tradisionele leier vir die hof behou. ${ }^{66}$ Ideaal gesproke behoort die waarnemer die hofgeding by te woon ten einde die getuienis eerstehands aan te hoor en te versamel, maar potensiële taalverskille kan konstruktiewe bywoning bemoeilik. In sulke omstandighede is die dienste van 'n betroubare tolk noodsaaklik, of die hofrekord, verkrygbaar by die tradisionele hof sowel as die landdroshof, kan die minimum inligting van die geding bevat.

Navorsingstegnieke van kwantitatiewe, kwalitatiewe en deelnemende aard, kan benut word om die lewende reg waar te neem. Kwantitatiewe metodes het die voordeel van die versameling van 'n groot hoeveelheid gegewens, en geskied gewoonlik op selektiewe steekproefbasis. Dit veronderstel gewoonlik die gebruikmaking van 'n gestandaardiseerde vraelys. ${ }^{67}$ Kwalitatiewe navorsing verwys onder andere na groep-besprekings, deelnemerwaarneming by groepsbyeenkomste, begrafnisse, populêre sosiale geleenthede en in-diepte-onderhoudvoering met 'n spesifieke groep, byvoorbeeld kundige persone in die gemeenskap, tradisionele leiers wat op grond van hulle posisie in die gemeenskap of hul geartikuleerdheid, bevoeg is om inligting te verskaf. ${ }^{68}$ Kwalitatiewe navorsing verg deeglike beplanning en voorbereiding, sowel as die opleiding van veldwerkers, indien nodig. Dit is dikwels tydrowend en gaan met finansiële koste gepaard. ${ }^{69}$ Daar moet gewaak word teen agterdog ten opsigte van die vooroordele of agenda van die waarnemer, byvoorbeeld dat die navorsing namens 'n politieke party, die regering, of 'n bepaalde belangegroep gedoen word, of gerig is op die verydeling of omverwerping van 'n gevestigde praktyk. Besondere sorg moet aan die dag gelê word om die protokol van individuele tradisionele leiers en dié van die Nasionale Huis en onderskeie Provinsiale Huise van Tradisionele Leiers na te kom. ${ }^{70}$

\section{Vasstelling van die inheemse reg deur die howe}

Daar word geredelik aanvaar dat howe vertroud is met die reg wat hulle toepas. 'n Inheemsregtelike stelsel is egter nie onmiddellik toeganklik vir

66 Sien Bekker "Court Structure and Procedure" in Joubert (red) The Law of South Africa (LAWSA) 2uitg Vol 32 (2009) par 249 vir die mees resente oorsig van die hofstuktuur en prosedure.

67 Sien Becker en Hinz 87; en Becker 94. Die gebruikmaking van 'n gestandaardiseerde vraelys het potensieel verskeie nadele, byvoorbeeld, die beperkings van die taal waarin die vraelys opgestel is, dat terminologie of begrippe verkeerd geînterpreteer kan word en vreemd aan die respondente kan wees, en dat resultate wat nie in die opstel van die vraelys geantisipeer is nie, hul voordoen. Aan die NMMU moet klaring deur die Research Ethics Committee (Human), as sub-komitee van die NMMU Research, Technology and Innovation Committee, verkry word ten einde sodanige navorsing te magtig.

68 Becker en Hinz 87; en Becker 95.

69 Becker en Hinz 87. Sien ook Chuulu en Chileshe-Musanya 107-109 vir die problematiek verbonde aan onderhoudvoering.

70 Chuulu en Chileshe-Musanya 111. 
howe wat in 'n westerse bestel gesetel is nie, omdat die howe in die geval van die inheemse reg sosiaal verwyder is van die gemeenskappe wat hulle behoort te dien. ${ }^{71}$ Daarom word daar statutêr vir die vasstelling van die inheemse reg voorsiening gemaak.

Ingevolge artikel 1(1) van die Wysigingswet op Siviele Bewyslewering ${ }^{72}$ kan enige hof van die inheemse reg kennis neem vir sover sodanige reg geredelik en met voldoende sekerheid vasgestel kan word, tensy die inheemse reg in stryd is met die beginsels van die staatsgedragslyn of natuurlike geregtigheid. Sub-artikel (2) magtig 'n party om getuienis aan te voer van die inhoud van die regsreël wat by die betrokke verrigtinge in geskil is. Olivier et al wys op die volgende probleme inherent tot die artikel: ${ }^{73}$

- Die voorsittende beampte, byvoorbeeld die landdros, is nie verplig om van die inheemse reg geregtelik kennis te neem nie. Die howe word bloot deur artikel 1(1) daartoe gemagtig.

- Daar is geen verpligting op die regsprekers om oor enige formele of praktiese kennis van, of opleiding in, die inheemse reg te beskik nie.

- Indien die voorsittende beampte geen kennis van die inheemse reg (en sy bronne) het nie, sal dit tot wesenlike benadeling van die litigante lei.

- Daar is geen verpligting op die voorsittende beampte om deskundige getuies op te roep in gevalle waar hyself weens gebrekkige kennis van die inheemse reg nie met voldoende sekerheid van die inheemse reg geregtelik kennis kan neem nie.

- In sulke omstandighede word die onus en finansiële las op die partye geplaas om die inheemse reg te bewys deur getuienis van deskundige getuies aan die hof voor te lê.

In essensie beteken dit dat die howe nie noodwendig van wat die litigant/e as die lewende inheemse reg ken en beskou, geregtelik kennis kan neem in gevalle waar dit nie geredelik en met voldoende sekerheid vasgestel kan word nie. Met ongeveer 800 verskillende Suid-Afrikaanse tradisionele gemeenskappe, elk potensieel met sy eie regstelsel of bepaalde gewoonte/s, blyk dit onvermydelik te wees vir die litigante om van deskundige getuies gebruik te maak. Daar word vervolgens na twee voorbeelde van die gebruikmaking van (deskundige) getuies in dié verband verwys.

In Kewana $v$ Santam Insurance Co $L_{t d}{ }^{74}$ was die vraag na die geldigheid van 'n inheemsregtelike aanneming deur 'n vrou, me Kewana, van 'n minderjarige kind, Andile. Die broodwinner van die gesin, Kewana se dogter, is oorlede en die vraag het ontstaan of die respondent vir onderhoud jeens Andile verantwoordelik was. Die appellant het gebruik gemaak van die getuienis van die volgende persone: die deskundige getuienis van 'n (toe) swart Regsprofessor aan die Universiteit van Transkei, wat nie bloot 'n spesialis in die inheemse reg was nie, maar ook kennis van die gewoonte van aanneming in sy persoonlike hoedanigheid gehad het; 'n buurman van

71 Bennett Human Rights and African Customary Law 64.

7245 van 1988.

73 Olivier et al 612.

7419934 SA 771 (Tk AD). 
die appellant, wat die aannemingseremonie bygewoon het; asook 'n distrikskommissaris van die koninklike bloedlyn, wat soos die professor, 'n kundige van aanneming in die gebied was.

Die respondent het die volgende getuies gebruik: die hoof van die tradisionele gesag waar die appellant woonagtig was (hy was onbekend met die praktyk van aanneming deur vroue, maar kon dit nie total negeer nie); 'n hoofman in die betrokke distrik; asook 'n blanke akademikus wat 12 jaar lank navorsing in die inheemse reg in Zimbabwe, en nie in die Transkei nie, gedoen het. Die hof het die getuies van die appellant weens hul persoonlike ervaring en waarnemings van die gewoonte in die Transkei self meer oortuigend as dié van die respondent bevind. ${ }^{75}$

In Mabuza $v$ Mbatha $^{76}$ was die geldigheid van 'n gebruiklike huwelik ingevolge Swazi-reg in dispuut. Die eiseres het 'n egskeidingsgeding, gepaardgaande met 'n versoek vir die beheer en toesig oor die eiseres en verweerder se kind en onderhoud ten opsigte van die kind, teen die verweerder aanhangig gemaak. Die verweerder het aangevoer dat die sogenaamde "huwelik" ongeldig was omdat spesifieke gebruike in die oorhandiging van die bruid nie nagekom is nie. In dié saak het die eiseres gebruik gemaak van die deskundige getuienis van 'n blanke professor met op daardie stadium 37 jaar-ervaring as akademikus aan verskeie universiteite. Omdat die getuie nie spesifiek 'n kundige in die Swazi-reg was nie en sy algemene getuienis oor huweliksvereistes en die interne ontwikkeling van die inheemse reg in handboeke vindbaar was, het die hof dit nie as van besondere hulp beskou nie. ${ }^{77} \mathrm{Hy}$ is egter allermins as 'n swak getuie bestempel. Daarteenoor was die hof minder beïndruk met die verweerder se deskundige getuie, 'n Swazi, wat na bewering 22 jaar lank Swazi-reg toegepas het en 'n hoofadviseurspos vir 'n tradisionele gesagsraad in die Mpumalanga-provinsie beklee het. Die hof was van mening dat hy nie eerlik ("truthful") in die oordrag van sy kennis van die betrokke huweliksformaliteite was nie en die hof gevolglik nie daarop kon staatmaak nie. $^{78}$

\section{GEVOLGTREKKINGS}

Die vraag of die dosent toegerus is om die inheemse reg te onderrig is nie afhanklik van die geboorteplek en kulturele oriëntasie van die dosent nie, maar wel van die "wat" en "hoe" van onderrig, of in die woorde van Stewart, die inhoud wat gedoseer gaan word en die bronne waaruit die inhoud voortspruit. In dié verband kan die volgende gevolgtrekkings gemaak word:

- Die inheemse reg kan weens sy sosiale normatiewe onderbou nie in isolasie as vak aangebied word nie. Dit beteken dat daar erkenning gegee moet word aan die invloed van ander dissiplines, byvoorbeeld Antropologie.

5 774C-D.

20034 SA 218 (CPD).

77 Supra par 16.

78 Supra par 25. Sien ook Lehnert 2005 SAJHR 266. 
- Die inhoud van die inheemse reg is onlosmaaklik verbonde aan die Grondwet van die Republiek van Suid-Afrika, 1996, en verskeie inheemsregtelike reëls het reeds grondwetlike skrutinering ondergaan.

- Ideaal gesproke moet die inheemse reg soos dit toegepas word, aan studente onderrig word. Dit is egter weens verskeie redes nie maklik haalbaar nie. Van die faktore wat in ag geneem moet word, is die tradisioneel ongeskrewe aard van die inheemse reg, die potensieel veelvoudige weergawes van die reg soos dit in die ongeveer 800 SuidAfrikaanse tradisionele gemeenskappe toegepas word, en die gevolglike regsonsekerheid waartoe dit aanleiding kan gee.

- Die implikasie hiervan is dat daar dikwels oorwegend van die amptelike bronne van die inheemse reg in die onderrig en regstoepassing daarvan, gebruik gemaak word.

- Die skrywers insiens dien die amptelike weergawe van die inheemse reg dikwels as die vertrekpunt van onderrig, byvoorbeeld die onderskeie handboeke en artikels geskryf deur bekende en befaamde skrywers, maar onderworpe aan die beskikbaarheid en toeganklikheid van die weergawe/s van die lewende reg.

- Die vasstelling van die inhoud van die lewende inheemse reg is nie 'n eenvoudige taak nie. In die howe mag daar geregtelik van die inheemse reg kennis geneem word, met dien verstande dat dit geredelik en met voldoende sekerheid vasgestel kan word. Dié bepaling verhinder litigante egter nie om getuienis aan te voer van die inhoud van 'n regsreël wat in geskil is nie.

- Dit blyk dat regsprekers nie noodwendig in die inheemse reg geskool is nie, en weens verskeie redes, waaronder die toeganklikheid van die amptelike weergawe van die reg, 'n voorkeur vir die toepassing van die amptelike inheemse reg het.

- Daar blyk 'n tendens in die hoër howe te ontwikkel om die lewende inheemse reg toe te pas deur òf die relevante gewoonte te ontwikkel (die Transvaalse Provinsiale Afdeling in Mabena), ${ }^{79}$ of te beslis dat die gemeenskap self die gewoonte ontwikkel het (die Grondwetlike Hof in Shilubana). ${ }^{80}$

- Die lewende inheemse reg is vasstelbaar deur eie waarneming en/of die gebruikmaking van inligting en data deur ander veldwerkers en navorsers versamel en verwerk.

- Die antwoord op die vraag wat doseer behoort te word is opgesluit in die bestudering van die wyse/s waarop die tradisionele gemeenskappe self hul dispute besleg en hul stelsels intern ontwikkel het.

- Die antwoord op die vraag hoe die vak gedoseer behoort te word, is buigsaam. Die amptelike reg kan as vertrekpunt vir onderrig gebruik word, maar behoort aangevul en/of soms negeer te word deur voorbeelde van die lewende inheemse reg. Dit gaan van die dosent vereis om die vak in die konteks van die sosiale normatiewe oorsprong

\footnotetext{
79 Supra.

80 Supra.
} 
daarvan, sowel as die funksionaliteit van die onderskeie gewoontes, aan te bied.

\section{SLOTOPMERKING}

Om na die vraag van die kandidaatprokureur terug te keer: Is die skrywer, wat nie in 'n tradisionele gemeenskap grootgeword het nie en dus 'n buitestaander tot die inheemse reg is, geskik om die inheemse reg aan te bied? Die antwoord word eerstens bepaal deur die inhoud van die vak, en tweedens deur die wyse waarop dit aangebied word. In soverre die dosent haarself deur bloot die gebruikmaking van ou boeke beperk, word die dinamiese aard van die inheemse reg misken. Dosente moet hulself uiteraard van regsontwikkeling, soos vervat in regspraak, vergewis. Daarbenewens behoort dosente in hul aanbieding van die vak mildelik gebruik te maak van die resultate van veldnavorsing, nuuswaardige gebeurtenisse, inligting vervat in koerantberigte, sosio-politieke en ekonomiese verwikkelinge in soverre dit die inheemse reg raak, ten einde aan te toon dat die reg 'n lewende stelsel is. Studente behoort aangemoedig te word om hul belewing van die inheemse reg met hul mede-studente in die klas te deel, sonder dat daar 'n persepsie van voor- of afkeur deur die dosent is.

Sou die dosent, wat die inheemse reg in konteks en met verwysing na beide die lewende weergawe daarvan, sowel as die Grondwet aanbied, ooit 'n Koyana of Mqeke vra of sy geskik is om die vak aan te bied, sou dié gevierde skrywers in analogie tot Sanders, heel moontlik antwoord:

"As Digby Koyana en Richman Mqeke die Romeins-Hollandse reg kan verstaan en as inherent tot die gemenereg doseer, kan jy, ons blanke kollega, sekerlik die inheemse reg verstaan en doseer" ${ }^{\prime 1}$ (eie bewoording).

81 Met apologie aan Sanders 1999 Obiter 197. Sanders het in 'n gedenkuitgawe van Obiter, opgedra aan prof DS Koyana, 'n aantekening met verwysing na Koyana se boek Customary Law in a Changing Society (1980) oor "insiders" en "outsiders" van die Antropologie geskryf. Hy sluit sy aantekening soos volg af (197): "Had I ever asked Digby [Koyana] whether I would be able to understand his Customary Law in a Changing Society, he would have answered: 'If Digby Koyana can understand Roman-Dutch law, then you, my Dutch friend, can be made to understand African law." 


\section{UNIVERSITY OF CAPE TOWN \\ AFRICAN CUSTOMARY LAW ${ }^{82}$ \\ NOVEMBER 2009}

MARKS: $\quad 60$

TIME: $\quad 2$ hours $(+15$ minutes reading time $)$

EXAMINER: Prof FA de Villiers

\section{ANSWER ANY 6 OF THE 9 QUESTIONS (FOR 10 MARKS EACH)}

\section{QUESTION 1}

$\mathrm{X}$, classified as an African male, approaches you for advice on the validity of his marriages, informing you that:

(i) he has successively married three wives, B, C and D, all of whom are also classified as Africans;

(ii) that lobolo has been paid in respect of all three wives; and

(iii) his marriage to $\mathrm{C}$ took place in a church, with a minister of religion acting as a marriage officer, too.

What would be your considered opinion on any TWO of the following three scenarios?

(a) He married all three of them in the district of Cape Town in 1970, 1982 and 2001, respectively; and/or

(b) He married all three of them in KwaZulu districts, during the same years; and/or

(c) He married all three of them in Transkei districts, during the same years.

\section{QUESTION 2}

Answer either ONE of the following questions:

(a) Compare the (i) majority and (ii) minority judgments of the Constitutional Court in the Bhe case with the judgment of the Constitutional Court in the Shilubana case; or

\footnotetext{
82 'n Verpligte LLB-vak op finalejaarsvlak.
} 
(b) "How 'customary' is the Reform of Customary Law of Succession and Related Matters Act, 2009?" is a question that could be posed today. Explain:

(i) Response to this question; and

(ii) why this piece of legislation has been passed.

\section{QUESTION 3}

"In the area of dispute resolution, indigenous law is largely flexible. Its chief aim is the reaching of a just decision ... [l]ts procedures for the settlement of disputes emphasize reconciliation and restoration of harmony" (Dlamini in Bill of Rights Compendium (1998)).

Compare these "adjudication values" of traditional customary law with those of modern South African law.

\section{QUESTION 4}

"Over the past ten years, attempts to fill out the sparse framework provided by the Constitution have proved to be hugely controversial. The two new laws that are at the centre of the government's attempts to bring the traditional practice of traditional leadership into line with South Africa's new democratic values, the Traditional Leadership and Governance Framework Act and the Communal Land Rights Act, remain deeply problematic. They satisfy neither the traditional leaders who are seeking more security, nor those who argue that traditional government needs to transform radically to serve the new democracy" (Bennett and Murray in Constitutional Law of South Africa (2008)).

Give an overview of either ONE of the two pieces of legislation referred to.

\section{QUESTION 5}

"Spicing the syllabus with living customary law examples", is the title of a paper to be read at the forthcoming annual conference of Western and Eastern Cape Law Faculties and Law Schools. Write an essay on "living" customary law in South Africa today.

\section{QUESTION 6}

"Indigenous law needs to be developed, says Ngcobo", reads a heading in the Cape Times of 9 October 2009.

Explain your response to this newspaper report, in which the new Chief Justice had "urged law students and lecturers to engage in the debate" on the development of customary law. 


\section{QUESTION 7}

Views expressed on customary law in the "new" South Africa range, inter alia, from "Re-introducing African [c]ustomary Law to the South African Legal System" (Bennett 2009 American Journal of Comparative Law) to "Killing it softly" (Pieterse 2000 De Jure).

How would you debate the question as to whether "more" or "less" customary law has been recognized in the "new" South Africa than in the "old" South Africa?

\section{QUESTION 8}

Answer either ONE of the following:

(a) Write an essay on the different purposes served by the nqoma type of contract traditionally practised in Southern and other parts of Africa; or

(b) critically evaluate the Gumede judgment and the academic response that the Court should rather have "developed" the customary law concerned.

\section{QUESTION 9}

Internet searches for "lobolo/a" and even "soapie lobolo/a" yield a range of headings such as "The big business of lobola", "Girls 'sold" for lobola", and "Lobola is sexist".

(a) Mention different theories on the "real meaning and function" of lobolo/a in traditional customary law; and

(b) explain whether lobolo/a is a marriage requirement in terms of the Recognition of Customary Marriages Act, 1998. 
ADDENDUM B

NELSON MANDELA METROPOLITAN UNIVERSITY

CUSTOMARY LAW ${ }^{83}$

JUNE 2009

MARKS: $\quad 60$

TIME: $\quad 2$ hours

EXAMINER: Prof E Knoetze

\section{QUESTION 1}

Indicate whether the following statements are TRUE or FALSE. If considered FALSE, students are requested to CORRECT the statement.

(a) A customary marriage can be dissolved extra-judicially by the return of some of the lobola cattle.

(b) A civil marriage contracted by Blacks after 2 December 1988 is automatically out of community of property, with accrual.

(c) Family property may not be bequeathed in a will.

(d) In customary law contracts are real and not consensual.

(e) Isondlo is a form of delict in customary law.

(f) Legal representation is denied to litigants in the traditional courts of chiefs and headmen.

(g) The estate of a deceased Black may only be administered by a Magistrate.

(h) Two Whites may conclude a customary marriage. Not to allow them, would constitute unfair discrimination.

(i) Since 15 November 2000 both parents of a Black woman must consent to a customary marriage between their daughter and the groom, irrespective of how old the bride is.

(j) Customary law is subject to the Constitution of the Republic of South Africa of 1996.

(k) Customary law is subject to the common law.

(I) The Small Claims Court has no jurisdiction over matters that have arisen in customary law.

(m) The concept of prescription is unknown in customary law.

(n) The Communal Rights Tenure Act of 2009 empowers the Minister to set up land-tenure boards to advise him/her on land matters and to supervise the workings of the land administration committees.

83 'n Verpligte LLB-vak op tweedejaarsvlak. 
(o) All traditional courts are unconstitutional and should be abolished.

[15x2=30]

\section{QUESTION 2}

Answer the following questions with relation to adultery as delict in customary law:

(a) What conduct constitutes adultery;

(b) what evidence can be submitted as proof of the commission of the delict;

(c) four grounds of justification which may be used by the defendant; and

(d) the usual compensation payable.

\section{QUESTION 3}

A farmer in the Cookhouse district, Mr Angus Barber, comes to see you for legal advice regarding a request from the Kakana family group whose ancestors were buried on land which now constitutes Mr Barber's farm, Milly Milly. The request is that the land must be made available for further burials, and that for each visit Mr Barber must tolerate at least three Blunden Transport buses with funeral-goers for the duration of the respective burials.

Advise Mr Barber on the question whether the Kakana family group may indeed bury their deceased on his land. Motivate your answer and refer to applicable legislation and case law.

\section{QUESTION 4}

Indicate which court(s) will have jurisdiction as a court of first instance in the following cases:

(a) The dissolution of a customary marriage.

(b) The defloration of a young virgin girl. 